\title{
Rapid determination of flavonoids and phenolic acids in grape juices and wines by RP-HPLC/DAD: Method validation and characterization of commercial products of the new Brazilian varieties of grape
}

\author{
Carla Valéria da Silva Padilha ${ }^{\mathrm{a}, \mathrm{d}}$, Gabriela Aquino Miskinis ${ }^{a}$, Marcelo Eduardo Alves Olinda de Souza ${ }^{\text {, }}$ \\ Giuliano Elias Pereira $^{\mathrm{b}}$, Débora de Oliveira ${ }^{\mathrm{c}}$, Marilde Terezinha Bordignon-Luiz ${ }^{\mathrm{d}}$, Marcos dos Santos Lima ${ }^{\mathrm{a}, *}$ \\ ${ }^{a}$ Instituto Federal do Sertão Pernambucano, Departamento de Tecnologia em Alimentos, Campus Petrolina, Rod. BR 407 Km 08, S/N, Jardim São Paulo, CEP 56314-520 Petrolina, \\ PE, Brazil \\ ${ }^{\mathrm{b}}$ Empresa Brasileira de Pesquisa Agropecuária - Embrapa Semiárido/Uva e Vinho, Rodovia BR 428, Km 152, CP 23, CEP 56302-970 Petrolina, PE, Brazil \\ ${ }^{\mathrm{C}}$ Universidade Federal de Santa Catarina, Departamento de Engenharia Química e de Alimentos, Campus Trindade, Trindade, 88040-900 Florianópolis, SC, Brazil \\ ${ }^{\mathrm{d}}$ Universidade Federal de Santa Catarina, Departamento de Ciência e Tecnologia de Alimentos, Rod. Admar Gonzaga 1346, Itacorubi, 88034-001 Florianópolis, SC, Brazil
}

\section{A R T I C L E I N F O}

\section{Article history:}

Received 23 November 2016

Received in revised form 26 January 2017

Accepted 27 January 2017

Available online 30 January 2017

\section{Keywords:}

Bioactive compounds

Antioxidant activity

Vitis labrusca $\mathrm{L}$.

Reactive oxygen species

\begin{abstract}
A B S T R A C T
A method for rapid determination of phenolic compounds by reversed-phase high-performance liquid chromatography (RP-HPLC), using a new column of faster resolution was validated and used to characterize commercial products produced with new grape Brazilian varieties of Northeast of Brazil. The in vitro antioxidant activity was also measured. The method showed linearity $(\mathrm{R}>0.9995)$, good precision (CV\% < 2.78), recovery (91.8-105.1\%) and limits of detection $\left(0.04-0.85 \mathrm{mg} \mathrm{L}^{-1}\right)$ and quantification $(0.04-$ $1.41 \mathrm{mg} \mathrm{L}^{-1}$ ) according to other methods previously published with the difference of a run time of only $25 \mathrm{~min}$. The results obtained in the characterization of the samples differed for juices and wines from other world regions, mainly because of the high values of (-)-epigallocatechin and trans-caftaric acid. The products analyzed showed high antioxidant activity, especially the wine samples with values higher than those from wines of different regions of the world.
\end{abstract}

(c) 2017 Elsevier Ltd. All rights reserved.

\section{Introduction}

Phenolic compounds are important plant metabolites present in grapes and derivatives such as wine and juices. These substances are related to sensory characteristics, chemical stability and associated with various health benefits for consumers of such products (Camargo, Regitano d'Arce, Biasoto, \& Shahidi, 2014; Garrido \& Borges, 2013; Toaldo et al., 2015). In terms of quantity, the major phenolics present in wines and juices belongs to the families of flavanols, anthocyanins and phenolic acids (Granato, Koot, Schnitzler, \& van Ruth, 2015; Leeuw, Kevers, Pincemail, Defraigne, \& Dommes, 2014; Lima et al., 2014).

The main flavanols found in wines and grape juices are catechin, epicatechin, epigallocatechin and procyanidins B1, B2 and B3, compounds associated with taste and various bioactive properties as in vitro antioxidant activity and in vivo antimicrobial and antiinflammatory (Granato, Carrapeiro, Fogliano, \& van Ruth, 2016; Leeuw et al., 2014; Scola et al., 2010). Anthocyanins are the main

\footnotetext{
* Corresponding author.

E-mail address: marcos.santos@ifsertao-pe.edu.br (M.d.S. Lima).
}

substances responsible for the color in wine and grape juices. The main anthocyanins present in wines and juices are malvidin, cyanidin, peonidin, delphinidin, petunidin and pelargonidin, which varieties Vitis vinifera $\mathrm{L}$. and Vitis labrusca $\mathrm{L}$. predominate in the forms of 3-monoglucoside and 3,5-diglucoside, respectively (Garrido \& Borges, 2013; Lambri et al., 2015; Nixdorf \& Her mosín-Gutiérrez, 2010). In products made from hybrid varieties (Vitis vinifera L. $\times$ Vitis labrusca L.) the presence of anthocyanins occurs in a mixture of mono and diglucosides (Granato et al., 2015; Lima et al., 2014). Phenolic acids are divided into hydroxybenzoic (HBA) and hydroxycinnamic (HCA). The main HBA acids present in juices and wines are protocatechuich, vanillin, gallic and syringic, and the main HCA are $\rho$-coumaric, caffeic, ferulic, and cis and trans cinnamic acid: caftaric, cutaric and fertaric (Garrido \& Borges, 2013; Granato et al., 2016; Leeuw et al., 2014; Toaldo et al., 2015).

The Sub-middle São Francisco Valley (SFV), located in the Northeast of Brazil, is a Brazilian region that has invested in the production of grape juices with new Brazilian varieties developed to produce high quality juices, as the "Isabel Precoce" (Vitis labrusca L.) and hybryds (Vitis vinifera L. $\times$ Vitis labrusca L.) "BRS 
Violeta”, “BRS Cora” and "BRS Magna” (Lima et al., 2014), where currently five companies produce about 1.5 million liters/year of commercial juices with these varieties. Grape juice in this region have been highlighted by the good bioactive content, high antioxidant activity associated with phenolic compounds, improving the ergogenic effect in recreational runners, in vivo antioxidant activity and possible reduction of inflammatory markers associated with its consumption (Camargo et al., 2014; Lima et al., 2014, 2015; Natividade, Corrêa, Souza, Pereira, \& Lima, 2013; Silva et al., 2015; Toscano et al., 2015). Because Brazil is a large consumer of Vitis labrusca L. wines and hybrids, three companies in the SFV began producing wines with the new Brazilian grape varieties. There was not found information on the phenolic composition and potential bioactive of the products of this region.

In recent years methods for rapid determination of phenolic compounds in grape juice and wine have been published. In most cases these compounds are analyzed by Reversed-Phase HighPerformance Liquid Chromatography (RP-HPLC) using a RP-C18 column types Core-Shell or rapid resolution (RR) for separating compounds (Dias, David, \& David, 2016; Fontana, Antoniolli, \& Bottini, 2016; Manns \& Mansfield, 2012). However, it was not found studies describing a methodology for determination of phenolic compounds in wines and grape juices using an RR type column RP-C18 $(100 \times 4.6,3.5 \mu \mathrm{m})$, being necessary to carry out work to implement this type of column for analysis in these matrices as its presents an option for quick analysis. The rapid separation of compounds on reversed phase columns decreases the runtime of the methods, the use of solvents and ultraviolet detectors lamps (UV), photodiode array (DAD) and fluorescence (FD), while minimizing wear on various HPLC system components.

In this context, the objective of this study was to validate a methodology for rapid determination of flavanols, anthocyanins and phenolic acids in grape juice and wine by RP-HPLC/DAD using a new column RR RP-C18 type $(100 \times 4.6 \mathrm{~mm}, 3.5 \mu \mathrm{m})$ and then to apply the validated method to characterize samples of grape juice and commercial wines produced with the new grape Brazilian varieties. In addition, in vitro activity of the studied compounds was measured.

\section{Material and methods}

\subsection{Chemicals and standards}

Trolox (6-hydroxy-2,5,7,8-tetramethylchroman-2-carboxylic acid), 2,20 -azino-bis (3-ethylbenzothiazoline-6-sulphonic acid) (ABTS) and 2,2-diphenyl-1-picrylhydrazyl (DPPH) radicals were purchased from Sigma-Aldrich (St. Louis, MO, USA). FolinCiocalteu reagent, ethyl alcohol, phosphoric acid, monopotassium phosphate and potassium persulfate were obtained from Merck (Darmstadt, Germany). Methanol was supplied by J.T. Baker (Phillipsburg, NJ, USA). Ultrapure water obtained from a Milli-Q system (Millipore, Bedford, MA, USA) was used to prepare all solutions. Standards included gallic, syringic, $\rho$-coumaric, caffeic and trans-caftaric acid, (+)-catechin, (-)-epicatechin gallate, (-)-epigallocatechin, procyanidin B1 and B2, cyanidin 3,5-diglucoside, malvidin 3,5-diglucoside, pelargonidin 3,5diglucoside from Sigma-Aldrich (St. Louis, MO, USA). Malvidin 3-O-glucoside and peonidin 3-O-glucoside from Extrasyntese (Genay, France).

\subsection{Samples}

To validate the methodology, commercial samples of grape juice and wine from new cultivars of Brazilian grapes from SFV were analyzed. The samples characterization was carried out using the previously validated method, where 8 commercial products from local industries were collected. For each sample 3 bottles of different batches were purchased, totalizing 24 samples. The commercial products correspond to 5 labels of grape juice, coded as GJA, GJB, GJC, GJD e GJE and 3 of red wines, coded as WF, WG, WH.

According to the information by the industries the juices were elaborated with the grapes: Isabel Precoce e BRS Cora (samples GJA and GJB); Isabel Precoce e BRS Magna (sample GJC) e Isabel Precoce e BRS Violeta (samples GJD and GJE). The grapes used in the preparation of the wines were: Isabel Precoce e BRS Cora (samples WF and WG) and Isabel Precoce e Bordô (sample WH). Classical analyses of $\mathrm{pH}$, soluble solids and titratable acidity were carried out for samples of grape juice. Values varied from 3.07 to 3.58 (pH); 16.3 to $21.9{ }^{\circ}$ Brix (soluble solids); and 5.8 to $8.6 \mathrm{~g} \mathrm{~L}^{-1}$ of tartaric acid equivalent (titratable acidity). Samples of wine varied from 3.51 to $3.89(\mathrm{pH})$ and 5.0 to $8.1 \mathrm{~g} \mathrm{~L}^{-1}$ tartaric acid equivalent (titratable acidity), respectively.

\subsection{Instruments and conditions}

Analyses were performed using an Agilent 1260 Infinity LC System (Santa Clara - USA) equipped with a model G1311C quaternary solvent pump and degasser, a thermostatted column compartment (G1316A), autosampler (G1329B) and a diode array detector - DAD (G1315D). The data collect and analyses were carried out using the software OpenLAB CDS ChemStation Edition (Agilent Technologies, Santa Clara - USA).

The chromatographic conditions used were adapted from the earlier methodology described by Manns and Mansfield (2012). The detection of compounds was performed at $220 \mathrm{~nm}$ for (+)catechin, (-)-epigallocatechin, (-)-epicatechin gallate, procyanidin $\mathrm{B} 1$ and procyanidin $\mathrm{B} 2 ; 280 \mathrm{~nm}$ for gallic acid and syringic acid; $320 \mathrm{~nm}$ for caftaric acid, caffeic acid and $\rho$-coumaric acid; and $520 \mathrm{~nm}$ for malvidin 3,5-diglucoside, cyanidin 3,5-diglucoside, pelargonidin 3,5-diglucoside, peonidin 3-O-glucoside and malvidin 3-O-glucoside.

The chromatograms obtained for the standard solutions of the 15 studied phenolic compounds and their respective retention time are presented in Fig. 1. The column used was a Zorbax Eclipse Plus $\mathrm{RP}^{-\mathrm{C}_{18}}(100 \times 4.6 \mathrm{~mm}, 3.5 \mu \mathrm{m})$ (rapid resolution column) and the pre-column was a Zorbax $C_{18}(12.6 \times 4.6 \mathrm{~mm}, 5 \mu \mathrm{m})$, both manufactured by Zorbax (USA). The oven temperature was maintained at $35^{\circ} \mathrm{C}$, the injection volume was $20 \mu \mathrm{L}$ (grape juice/wine previously diluted $500 \mu \mathrm{L}+1000 \mu \mathrm{L}$ in phase A and membrane filtration of $0.45 \mu \mathrm{m}$ (Chromafil ${ }^{\circledR}$ Xtra, Macherey-Nagel - Germany)) and the flow rate was $0.8 \mathrm{~mL} \mathrm{~min}{ }^{-1}$. The gradient used in the separation was $0-5$ min: $5 \% \mathrm{~B}$; 5-14 min: $23 \% \mathrm{~B}$; $14-22 \mathrm{~min}: 26 \% \mathrm{~B}$; 22-25 min: $80 \% \mathrm{~B}$, where solvent $\mathrm{A}$ was $0.1 \mathrm{M}$ phosphoric acid solution ( $\mathrm{pH} 2.0)$ and solvent $\mathrm{B}$ was methanol acidified whit $\mathrm{H}_{3} \mathrm{PO}_{4} 0.5 \%$.

\subsection{Method validation}

The validation parameters, according to the guide for validation and analytical quality control published of the Ministry of Agriculture of Brazil (BRASIL, 2011), employing assays with standard solutions, blank samples and spiked samples, were calibration curve linearity, specificity, precision, accuracy, recovery and limits of detection and quantification.

\subsubsection{Linearity}

An external standard calibration methodology was applied. Five solutions with different concentrations of phenolic compounds were prepared by consecutive dilutions in the mobile phase A from a stock solution. Calibration curves for concentration versus 


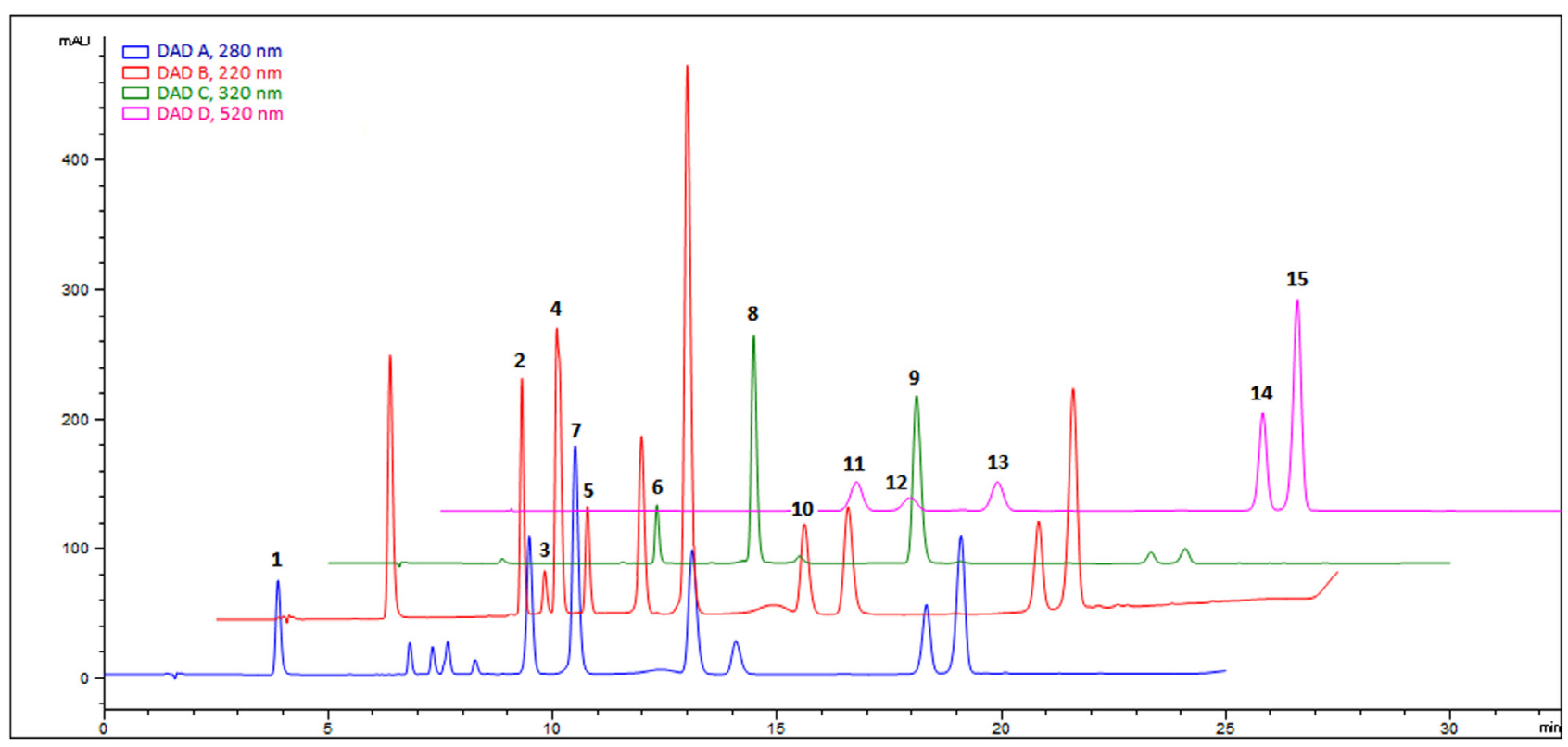

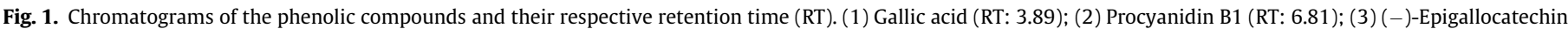

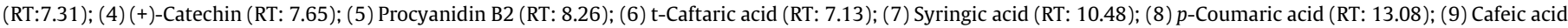

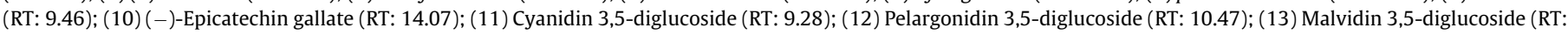
12.34); (14) Peonidin 3-O-glucoside (RT: 18.34); (15) Malvidin 3-O-glucoside (RT: 19.12).

response ratio were plotted for each analyte determined from the regression analysis using the least squares method.

\subsubsection{Specificity}

To assess the specificity of the method were injected samples of red wine and grape juice. The peaks in the chromatogram obtained for the compounds examined were subjected to the threshold test for assessing the purity of peak, settling the purity factor limit $\geqslant 990$ (match factor), with software OpenLAB CDS 3D UV (Agilent Technologies, USA). The match factor represents the degree of similarity between the spectra. The comparison of two spectra gives the match factor, which was defined as:

MatchFactor $=\frac{10^{3} \times\left\{\sum x \times y-\left(\frac{\sum x \times \sum y}{n}\right)\right\}^{2}}{\left\{\sum x^{2}-\left(\frac{\sum \times \times \sum x}{n}\right)\right\} \times\left\{\sum y^{2}-\left(\frac{\sum y \times \sum y}{n}\right)\right\}}$

The values $x$ and $y$ are measured absorbance in the first and second spectrum, respectively, at the same wavelength; $n$ is the number of data points and $\Sigma$ the sum of the data. Generally, values above 990 indicate that the spectra are similar. Values between 900 and 990 indicate there is some similarity, and below 900 indicate the spectra are different (Agilent, 2008).

\subsubsection{Precision and recovery}

The precision was evaluated by the variation coefficient (VC\%) obtained from the results of six injections from the mixture of grape juice/wine spiked by the addition of external standards of studied compounds. The study of recovery was performed by spiking the same sample of grape juice/wine with standard solutions within the concentrations range. The recovery was calculated comparing the values obtained for each compound "spiked" in relation to the initial value contained in sample.

\subsubsection{Limit of detection (LOD) and limit of quantification (LOQ)}

The LOD and LOQ were obtained considering the method described by Hubaux and Vos (1970). Three standards were pre- pared at concentrations close to the LOD estimated and analyzed in triplicate. An analytical curve was constructed by plotting the values obtained from the analysis of the standards versus the actual values, obtaining the slope of the curve, intercept and coefficient of correlation. The residual standard deviation (RSD) was calculated by comparing the values obtained in the analysis of the actual values. LOD and LOQ were established as 3 and 10 times the RSD, respectively, added with the intercept of the curve.

\subsection{Determination of the bioactive content: total phenolics and total monomeric anthocyanins}

The total phenolics content of the red wine and grape juice were determined at $765 \mathrm{~nm}$ after reacting with Folin-Ciocalteu reagent (Singleton \& Rossi, 1965). Gallic acid was used as the standard and the phenolic concentrations in wine and juice samples were expressed as mg of gallic acid equivalents (GAE)/L of wine/grape juice.

The total monomeric anthocyanins content was determined through the pH-differential method described by Giusti and Wrolstad (2001). The samples were diluted with buffer solutions of $\mathrm{KCl} 0.025 \mathrm{M}$ ( $\mathrm{pH} 1.0$ ) and $\mathrm{CH}_{3} \mathrm{COONa} 0.4 \mathrm{M}(\mathrm{pH} 4.5)$ and absorbance measurements were performed at 520 and $700 \mathrm{~nm}$, respectively. The total monomeric anthocyanins content was expressed as malvidin-3-glucoside equivalents in $\mathrm{mg} \mathrm{L}^{-1}$.

\subsection{Antioxidant activity}

The in vitro antioxidant assays were carried out to determine the free radical scavenging capacity using the DPPH radical $(2,2-$ diphenyl-1-picrylhydrazyl), ABTS radical (2,2'-azinobis-(3-ethyl benzothiazoline-6-sulfonic acid)) and hydrogen peroxide, according to the standard methods (Kim, Guo, \& Packer, 2002; Re et al., 1999; Ruch, Cheng, \& Klaunig, 1989). All analyses were performed in triplicate. The analytical standard (Trolox) was used to construct the calibration curves $\left(0.2-2.0 \mathrm{mM} \mathrm{L}^{-1}\right)$. The results were expressed as Trolox equivalents per litre of product ( $\left.\mathrm{MM} \mathrm{TEAC} \mathrm{L}^{-1}\right)$. 
ABTS: The ABTS radical ( $1 \mathrm{mM}$ ) was formed through the reaction of $7 \mathrm{mM}$ ABTS in $140 \mathrm{mM}$ potassium persulfate in the absence of light for $16 \mathrm{~h}$. The solution was then diluted in ethanol until an absorbance of $0.700 \pm 0.05$. The ABTS radical scavenging activity of the samples was determined through the rate of decay in the absorbance at $734 \mathrm{~nm}$ determined at time $\mathrm{t}=0 \mathrm{~min}$ and at time $\mathrm{t}=6$ min after the addition of samples.

$D P P H$ : The DPPH method the antioxidant activity of the samples was assessed through the rate of decay in the absorbance at $517 \mathrm{~nm}$. The DPPH radical solution $(1 \mathrm{mM})$ was prepared in ethanol and diluted to an absorbance of $0.900 \pm 0.05$. The absorbance of the DPPH solution was determined at time $t=0 \mathrm{~min}$ and 30 min after the addition of sample.

Hydrogen Peroxide Scavenging Activity $\left(\mathrm{H}_{2} \mathrm{O}_{2}\right)$ : A solution $0.4 \mathrm{~mol} \mathrm{~L}^{-1}$ of hydrogen peroxide was prepared in phosphate buffer ( $\mathrm{pH}$ 7.4) and its concentration was determined spectrophotometrically from absorption at $230 \mathrm{~nm}$. The grape juice and red wine samples $(0.4 \mathrm{~mL})$ were mixed with hydrogen peroxide solution $(0.6 \mathrm{~mL})$, and the final volume was completed to $3 \mathrm{~mL}$ with the phosphate buffer. The absorbance value of the reaction mixture was recorded at $230 \mathrm{~nm}$ and determined 10 min later against a blank solution containing the phosphate buffer. The scavenging activity was calculated with the equation:

$$
\begin{aligned}
\mathrm{H}_{2} \mathrm{O}_{2} \text { scavenging activity }(\%)= & {\left[\left(\mathrm{ABS}_{\text {Control }}-\mathrm{ABS}_{\text {Sample }}\right) /\right.} \\
& \left.\left(\mathrm{ABS}_{\text {Control }}\right)\right] \times 100
\end{aligned}
$$

where $\mathrm{ABS}$ Control is the absorbance of $\mathrm{H}_{2} \mathrm{O}_{2}$ radical + phosphate buffer and $A B S$ sample is the absorbance of $\mathrm{H}_{2} \mathrm{O}_{2}+$ sample or Trolox. All analyses were performed in triplicate.

\subsection{Statistical analysis}

Statistical analysis was performed using SPSS version 17.0 for Windows (SPSS, Chicago, USA). The results obtained in the samples characterization were previously evaluated in terms of normality, by Shapiro-Wilk test, and then were submitted to analysis of variance (ANOVA) and Tukey test with a probability of error of $5 \%$ (Granato, Calado, \& Jarvis, 2014).

\section{Results and discussion}

\subsection{Method validation}

Before validation of the method, different elution gradients were studied for obtaining the best conditions for compounds separation in the column used.

\subsubsection{Linearity and specificity}

The values obtained for the correlation coefficient (R) and purity factor of the peaks (match factor) are shown in Table 1 . The Rvalues for 15 analyzed phenolic compounds ranged from 0.9995 to 1.0000 and demonstrated good linearity curves and calibration. According the values of $\mathrm{R}$ for calibration curves must be greater than 0.99 , which confirms that the linearity obtained in this work for the response to external standards is adequate for its intended purpose.

The specificity is the ability to have a method for measuring a substance exactly in the presence of other components that may be present in the sample, such as impurities, degradation products and other matrix components (Eurochem, 2014). In this method, the specificity was evaluated with use of the threshold test using the spectral purity factor (match factor) for the compounds studied in real matrices, as shown in Fig. 2 for a peak of epigallocatechin in grape juice. The values obtained for purity factor were $\geqslant 990$ for syringic acid, caffeic acid, $\rho$-coumaric acid, caftaric acid, catechin gallate, epicatechin, epigallocatechin, procyanidin B2 and peonidin 3 -glucoside (Table 1), indicating that the peaks obtained for these compounds are pure. For procyanidin B1 and malvidin 3,5diglucoside purity factor values were 955 and 909, respectively, and indicated that there was a good possibility that the peaks obtained for these compounds are pure. The compounds of gallic acid and malvidin-3-glycoside had purity factor lower than 900 , suggesting the possible existence of interference from other substances in the same retention time.

Results for specificity were considered suitable for the intended purposes, since most of the peaks obtained for the compounds studied showed good spectral purity. It is also noteworthy the good separation obtained for simultaneous analysis of 15 phenolic compounds studied in a single run of $25 \mathrm{~min}$.

The method used in this study was considered fast since in methods of phenolic compounds determinations in grape juice and wine by RP-HPLC using classical columns type RP-C18 column $(250 \times 4.6 \mathrm{~mm}, 5 \mu \mathrm{m})$ runtimes times vary from 43 to 86 min (Obón, Díaz-García \& Castellar, 2011). Methods using columns RR $(150 \times 4.6 \mathrm{~mm}, \quad 3 \mathrm{mM})$ and Core-Shell $(100 \times 4.6 \mathrm{~mm}, 2.6 \mathrm{mM})$ runtimes covered ranged from 14 to 55 min (Manns \& Mansfield, 2012; Natividade et al., 2013; Tarola, Milano, \& Giannetti, 2007).

\subsubsection{Precision and recovery}

The values obtained for the precision (CV\%) of analyzed compounds ranged from 0.09 to 2.78 in grape juice matrix and from 0.11 to 0.66 for red wine (Table 1 ). The CV\% values obtained for the 15 studied phenolic compounds were lower than the maximum limit of $20 \%$ recommended by brazilian law for the concentration ranges studied here.

The results for the percentage of recovery of compound (RC\%) in the spiked samples are shown in Fig. 3. The RC values ranged from 94.8 to 105.1 for matrix of grape juice and 91.8 to 104.5 for red wines. These values are in accordance with the limits acceptable by brazilian legislation, which is $90-107 \%$, and were also similar to those obtained in several studies that validated methods for determination of phenolic compounds in wine and grape juice for RP-HPLC with UV detection (UV) light emitting diode arrangements (DAD), fluorescence (FD) and mass spectrum (MS) (Natividade et al., 2013; Tarola et al., 2007).

\subsubsection{Limit of detection and limit of quantification}

To obtain the LOD and LOQ values, the standard deviation values of the residues (RSD) were multiplied for 3 and 10, respectively, and added to the intercept of the curve next to the estimated LOD (Hubaux \& Vos, 1970).

For the 15 phenolic compounds studied, the LOD and LOQ ranged from 0.04 to $0.85 \mathrm{mg} \mathrm{L}^{-1}$ and 0.04 to $1.41 \mathrm{mg} \mathrm{L}^{-1}$, respectively (Table 1). The LOD and LOQ values obtained in this study are in agreement with those found in other validation studies for analysis of phenolic compounds in juices and wines by HPLC-UV (Tarola et al., 2007), HPLC-DAD (Manns \& Mansfield, 2012), HPLC-DADFD (Natividade et al., 2013; Silva et al., 2015) and HPLC-DAD-MS, demonstrating that the studied method has good sensitivity for quantifying these compounds.

The terms limit of quantitation (LOQ) and limit of detection (LOD) is used to demonstrate the ability of the method of quantifying/detecting low concentrations of a substance (Eurachem, 2014). The LOD and LOQ values obtained in the validation of this method are considered suitable for the intended purpose, since they were smaller than the minimum values normally reported in the literature for characterization of samples of wine and grape juice (Granato et al., 2015; Leeuw et al., 2014; Lima et al., 2014; Toaldo et al., 2015). 
Table 1

Results for the parameters of method validation of rapid determination of phenolic compounds in wines and grape juices by RP-HPLC/DAD.

\begin{tabular}{|c|c|c|c|c|c|c|c|c|c|}
\hline \multirow[t]{2}{*}{ Phenolic compounds } & \multirow{2}{*}{$\begin{array}{l}\text { Calibration } \\
\text { range } \\
\left(\mathrm{mg} \mathrm{L}^{-1}\right)\end{array}$} & \multirow[t]{2}{*}{ Calibration curve } & \multirow{2}{*}{$\begin{array}{l}\text { Correlation } \\
\text { coefficient (r) }\end{array}$} & \multicolumn{2}{|c|}{ Precision (CV\%) } & \multirow{2}{*}{$\begin{array}{l}\text { Specificity (purity } \\
\text { factor) }\end{array}$} & \multirow[t]{2}{*}{ RSD } & \multirow{2}{*}{$\begin{array}{l}\text { LOD } \\
\left(\mathrm{mg} \mathrm{L}^{-1}\right)\end{array}$} & \multirow{2}{*}{$\begin{array}{l}\text { LOQ } \\
\left(\mathrm{mg} \mathrm{L}^{-1}\right)\end{array}$} \\
\hline & & & & $\begin{array}{l}\text { Grape } \\
\text { juice }\end{array}$ & $\begin{array}{l}\text { Red } \\
\text { wine }\end{array}$ & & & & \\
\hline \multicolumn{10}{|l|}{ Phenolic acids } \\
\hline Gallic acid & $0.55-17.5$ & $Y=7.953 X+2.480$ & 0.9995 & 0.25 & 0.12 & 872 & 0.0024 & 0.12 & 0.14 \\
\hline Syringic acid & $0.55-17.5$ & $Y=47.315 X+1.255$ & 0.9999 & 0.28 & 0.31 & 1000 & 0.0028 & 0.11 & 0.13 \\
\hline p-Coumaric acid & $0.55-17.5$ & $Y=14.626 X-0.154$ & 1.0000 & 0.24 & 0.27 & 1000 & 0.0025 & 0.10 & 0.12 \\
\hline Cafeic acid & $0.55-17.5$ & $\mathrm{Y}=19.929 \mathrm{X}-0.225$ & 1.0000 & 0.23 & 0.24 & 1000 & 0.0025 & 0.10 & 0.12 \\
\hline $\begin{array}{l}\text { Caftaric acid } \\
\text { Flavanols }\end{array}$ & $0.55-17.5$ & $Y=5.039 X+0.190$ & 0.9999 & 0.29 & 0.27 & 1000 & 0.0010 & 0.09 & 0.10 \\
\hline$(+)$-Catechin & $0.55-17.5$ & $Y=24.639 X+0.705$ & 0.9999 & 0.26 & 0.13 & 995 & 0.0008 & 0.06 & 0.07 \\
\hline $\begin{array}{l}(-) \text {-Epicatechin } \\
\text { gallate }\end{array}$ & $0.55-17.5$ & $Y=9.072 X+0.352$ & 0.9997 & 0.40 & 0.37 & 1000 & 0.0019 & 0.06 & 0.07 \\
\hline (-)-Epigallocatechin & $0.55-17.5$ & $Y=3.615 X+0.405$ & 0.9995 & 0.29 & 0.11 & 1000 & 0.0014 & 0.04 & 0.05 \\
\hline Procyanidin B1 & $0.31-10.0$ & $Y=37.953 X-1.980$ & 0.9998 & 0.31 & 0.14 & 955 & 0.0025 & 0.10 & 0.12 \\
\hline Procyanidin B2 & $0.31-10.0$ & $Y=16.174 X+0.274$ & 0.9998 & 0.12 & 0.27 & 1000 & 0.0003 & 0.04 & 0.04 \\
\hline \multicolumn{10}{|l|}{ Anthocyanins } \\
\hline $\begin{array}{l}\text { Cyanidin 3,5- } \\
\text { diglucoside }\end{array}$ & $0.55-17.5$ & $Y=2.456 X+0.043$ & 0.9999 & 0.11 & 0.66 & 743 & 0.0013 & 0.07 & 0.08 \\
\hline $\begin{array}{l}\text { Malvidin 3,5- } \\
\text { diglucoside }\end{array}$ & $0.55-17.5$ & $Y=0.507 X-0.018$ & 1.0000 & 0.09 & 0.43 & 909 & 0.0045 & 0.24 & 0.28 \\
\hline $\begin{array}{l}\text { Pelargonidin 3,5- } \\
\text { diglucoside }\end{array}$ & $0.55-17.5$ & $Y=1.146 X+0.053$ & 0.9998 & 0.14 & 0.41 & ND & 0.0005 & 0.05 & 0.05 \\
\hline $\begin{array}{l}\text { Peonidin } 3-0- \\
\text { glucoside }\end{array}$ & $0.55-17.5$ & $Y=8.557 X-0.200$ & 1.0000 & 0.22 & 0.52 & 1000 & 0.0029 & 0.11 & 0.13 \\
\hline $\begin{array}{l}\text { Malvidin 3-O- } \\
\text { glucoside }\end{array}$ & $2.74-87.5$ & $Y=3.728 X-0.608$ & 1.0000 & 2.78 & 0.50 & 972 & 0.0805 & 0.85 & 1.41 \\
\hline
\end{tabular}

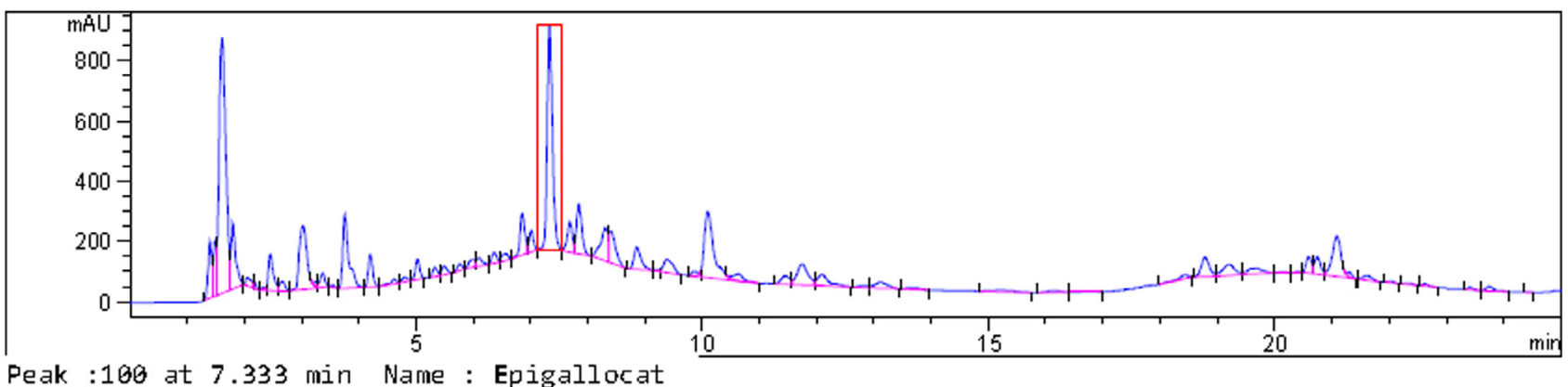

Peak :160 at 7.333 min Name : Epigallocat
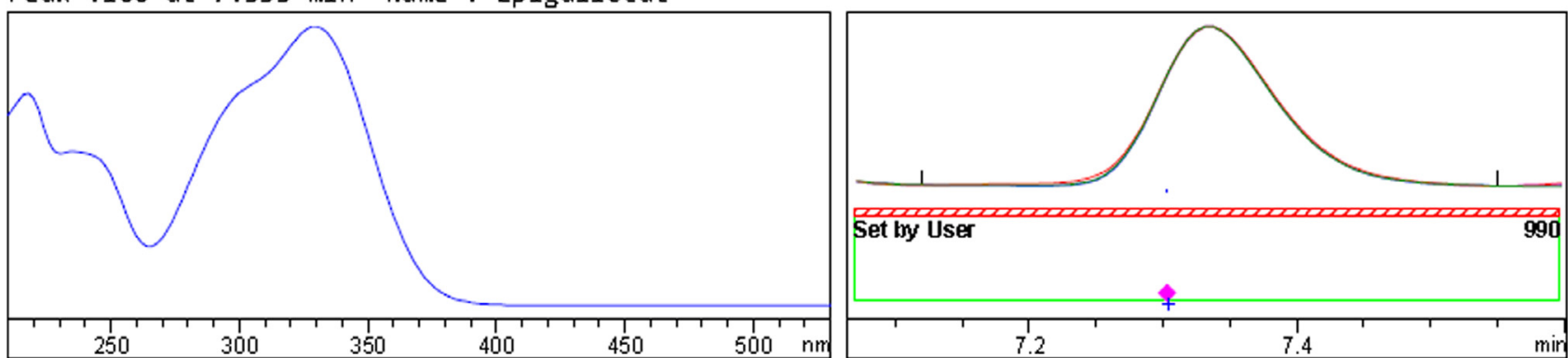

$\Rightarrow$ The purity factor is within the threshold limit. <-

Purity factor : 1606.606 (1 of 1 spectra is within the threshold limit.)

Threshold : 996.606 (Set by user)

Fig. 2. Threshold test for verification of spectral purity of (-)-epigallocatechin (DAD $220 \mathrm{~nm}$ ) peak in a run of grape juice.

3.2. Characterization of commercial products of the new Brazilian varieties of grape

3.2.1. Total phenolic content and total monomeric anthocyanins

The results of the determination of total phenolic content in red wines and grape juice produced with the new Brazilian grapes varieties by Folin-Ciocalteu method are presented in Table 2. Total phenolic content varied from 2135 to $2647 \mathrm{mg} \mathrm{L}^{-1}$ for the grapes juices and from 2003 to $4036 \mathrm{mg} \mathrm{L}^{-1}$ for the red wines.

Total phenolics values obtained in this study are in line with those mentioned in 62 samples of organic and conventional grape juice (Vitis labrusca L.) originated in Southern of Brazil, with values ranging from 1351 to $2712 \mathrm{mg} \mathrm{L}^{-1}$ (Margraf, Santos, Andrade, van Ruth, \& Granato, 2016). For red wines, the results are 


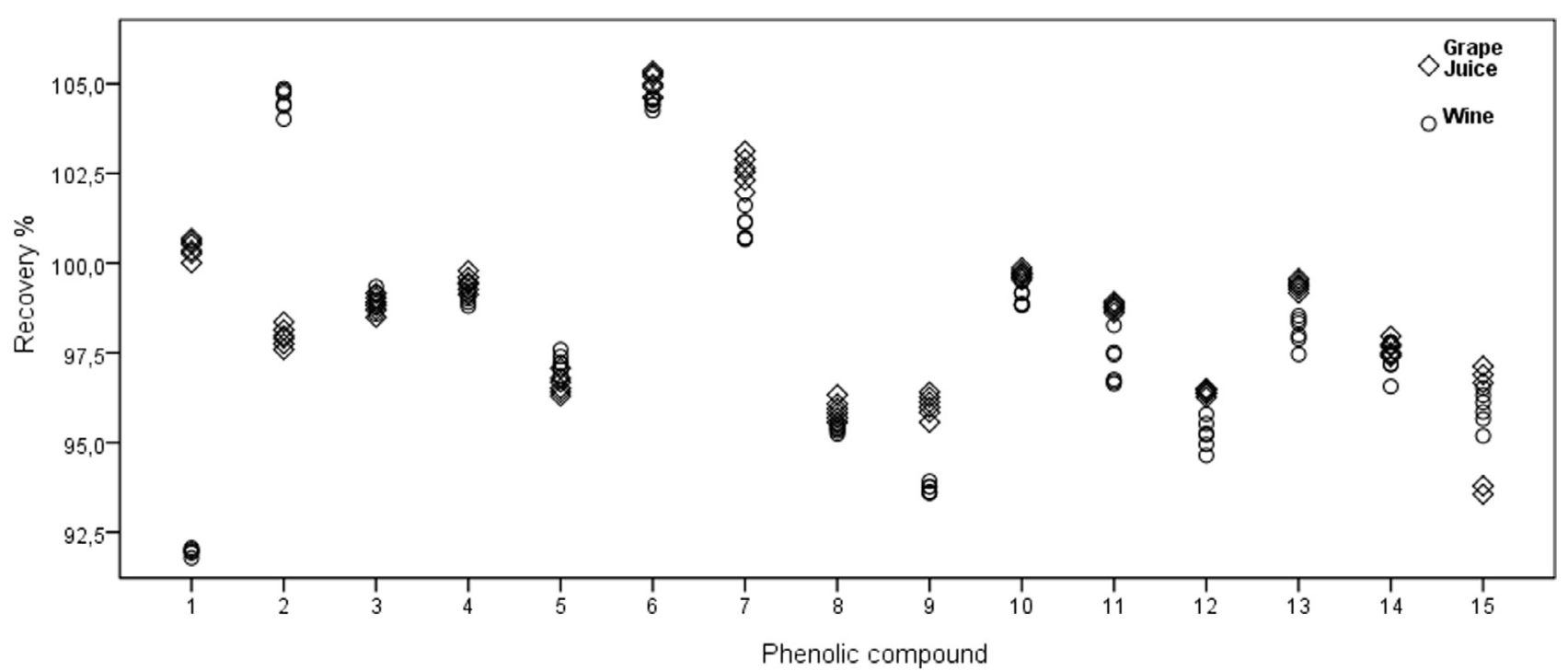

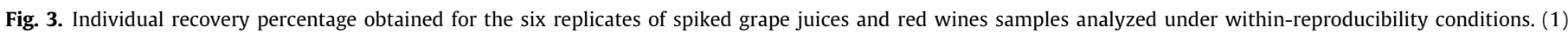

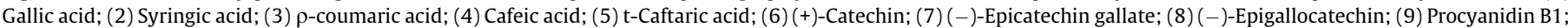

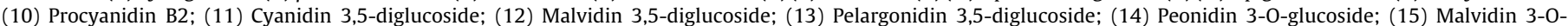
glucoside.

Table 2

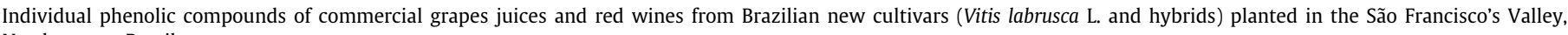
Northeastern Brazil.

\begin{tabular}{|c|c|c|c|c|c|c|c|c|}
\hline \multirow[t]{2}{*}{ Phenolic compounds } & \multicolumn{5}{|l|}{ Grape Juice } & \multicolumn{3}{|l|}{ Wine } \\
\hline & GJA & GJB & GJC & GJD & GJE & WF & WG & WH \\
\hline \multicolumn{9}{|l|}{ Phenolic acids } \\
\hline Gallic acid & $4.5 \pm 0.4 c$ & $3.6 \pm 2.9 \mathrm{c}$ & $16.7 \pm 3.5 b$ & $7.6 \pm 1.2 \mathrm{c}$ & $6.5 \pm 1.0 \mathrm{c}$ & $26.4 \pm 1.1 \mathrm{a}$ & $24.7 \pm 1.0 \mathrm{a}$ & $16.9 \pm 2.6 b$ \\
\hline Syringic acid & $1.1 \pm 0.1 \mathrm{c}$ & $1.9 \pm 1.0 \mathrm{c}$ & $5.1 \pm 0.5 a$ & $5.6 \pm 0.4 a$ & $2.5 \pm 0.3 b$ & $2.1 \pm 0.2 \mathrm{ab}$ & $2.0 \pm 0.1 \mathrm{ab}$ & $1.1 \pm 0.3 c$ \\
\hline$p$-Coumaric acid & $2.2 \pm 0.1 \mathrm{e}$ & $2.6 \pm 2.0 \mathrm{de}$ & $10.0 \pm 3.2 b c$ & $7.2 \pm 1.8 \mathrm{~cd}$ & $4.3 \pm 0.1 \mathrm{de}$ & $2.6 \pm 0.1 \mathrm{de}$ & $15.8 \pm 0.1 \mathrm{a}$ & $13.7 \pm 2.8 \mathrm{ab}$ \\
\hline Cafeic acid & $3.1 \pm 0.4 d$ & $5.1 \pm 2.7 \mathrm{~cd}$ & $12.8 \pm 1.7 \mathrm{ab}$ & $14.9 \pm 1.3 \mathrm{a}$ & $6.7 \pm 0.1 \mathrm{bcd}$ & $3.6 \pm 0.1 \mathrm{~d}$ & $18.8 \pm 0.1 \mathrm{a}$ & $11.7 \pm 6.2 \mathrm{abc}$ \\
\hline Caftaric acid & $274.9 \pm 21.5 \mathrm{abc}$ & $233.9 \pm 179.4 \mathrm{abc}$ & $365.5 \pm 47.6 a$ & $343.0 \pm 22.2 \mathrm{ab}$ & $290.7 \pm 0.3 \mathrm{ab}$ & $6.6 \pm 5.9 \mathrm{~d}$ & $167.4 \pm 0.9 \mathrm{bcd}$ & $91.3 \pm 21.4 \mathrm{~cd}$ \\
\hline$\sum$ phenolic acids & $285.8 \pm 22.5$ & $247.1 \pm 188.0$ & $410.1 \pm 56.5$ & $378.4 \pm 26.9$ & $310.7 \pm 1.8$ & $41.3 \pm 7.4$ & $228.7 \pm 2.2$ & $134.7 \pm 33.3$ \\
\hline \multicolumn{9}{|l|}{ Flavanols } \\
\hline (-)-Epicatechin gallate & ND & $0.9 \pm 0.9 \mathrm{a}$ & ND & ND & $0.7 \pm 0.1 \mathrm{a}$ & $3.3 \pm 3.1 \mathrm{a}$ & ND & $1.7 \pm 0.9 \mathrm{a}$ \\
\hline (-)-Epigallocatechin & $275.1 \pm 21.5 \mathrm{ab}$ & $232.9 \pm 176.9 \mathrm{ab}$ & $368.2 \pm 46.7 \mathrm{a}$ & $349.1 \pm 25.9 a$ & $284.4 \pm 0.1 \mathrm{ab}$ & $217.7 \pm 5.1 \mathrm{ab}$ & $265.1 \pm 0.0 \mathrm{ab}$ & $128.5 \pm 27.0 b$ \\
\hline Procianidin B1 & $7.1 \pm 0.0 \mathrm{abc}$ & $4.4 \pm 3.1 c$ & $9.9 \pm 0.9 \mathrm{ab}$ & $5.4 \pm 2.5 b c$ & $4.2 \pm 0.2 b c$ & $11.0 \pm 0.3 a$ & $7.6 \pm 0.0 \mathrm{abc}$ & $6.9 \pm 2.4 \mathrm{abc}$ \\
\hline Procianidin B2 & $5.8 \pm 0.1 d$ & $9.5 \pm 3.8 \mathrm{~cd}$ & $17.0 \pm 1.7 \mathrm{ab}$ & $10.3 \pm 4.9 \mathrm{~cd}$ & $8.9 \pm 0.4 d$ & $29.3 \pm 0.2 \mathrm{a}$ & $23.6 \pm 0.0 \mathrm{ab}$ & $26.3 \pm 4.3 \mathrm{a}$ \\
\hline$\sum$ flavanols & $297.4 \pm 22.2$ & $256.8 \pm 185.6$ & $410.1 \pm 50.7$ & $372.2 \pm 36.9$ & $311.8 \pm 1.0$ & $271.1 \pm 13.0$ & $309.1 \pm 0.2$ & $187.9 \pm 40.1$ \\
\hline \multicolumn{9}{|l|}{ Anthocyanins } \\
\hline Cyanidin 3,5-diglucoside & ND & $12.8 \pm 9.9 \mathrm{bc}$ & $1.5 \pm 0.5 \mathrm{~cd}$ & $4.2 \pm 1.5 \mathrm{bcd}$ & $25.1 \pm 0.0 \mathrm{a}$ & $0.8 \pm 0.8 \mathrm{~d}$ & $6.0 \pm 0.0 \mathrm{bcd}$ & $13.2 \pm 5.4 b$ \\
\hline Malvidin 3,5-diglucoside & $8.9 \pm 0.5 c$ & $9.8 \pm 1.2 \mathrm{c}$ & $11.9 \pm 1.5 c$ & $17.3 \pm 5.1 c$ & $136.5 \pm 0.0 \mathrm{a}$ & ND & $12.2 \pm 0.0 \mathrm{c}$ & $53.7 \pm 20.5 b$ \\
\hline $\begin{array}{l}\text { Pelargonidin 3,5- } \\
\text { diglucoside }\end{array}$ & ND & ND & ND & ND & ND & ND & ND & ND \\
\hline Peonidin 3-O-glucoside & $1.6 \pm 0.2 \mathrm{ab}$ & $1.5 \pm 0.9 \mathrm{ab}$ & $2.2 \pm 0.9 \mathrm{~b}$ & $0.7 \pm 0.1 \mathrm{c}$ & $5.1 \pm 0.0 \mathrm{a}$ & $0.4 \pm 0.1 \mathrm{c}$ & $0.4 \pm 0.0 \mathrm{c}$ & $0.4 \pm 0.1 \mathrm{c}$ \\
\hline Malvidin 3-O-glucoside & $10.5 \pm 1.3 c$ & $12.5 \pm 3.8 b$ & $10.7 \pm 3.0 c$ & $3.3 \pm 0.6 c$ & $36.8 \pm 0.0 c$ & $7.7 \pm 0.8 \mathrm{a}$ & $6.9 \pm 0.0 c$ & $2.4 \pm 0.0 c$ \\
\hline$\sum$ anthocyanin & $21.0 \pm 2.0$ & $36.6 \pm 15.8$ & $26.3 \pm 5.9$ & $25.5 \pm 7.3$ & $203.5 \pm 0.0$ & $8.9 \pm 1.7$ & $25.5 \pm 0.0$ & $69.7 \pm 26.0$ \\
\hline $\begin{array}{l}\text { Total monomeric } \\
\text { anthocyanins }\end{array}$ & $88.4 \pm 1.4 c$ & $177.9 \pm 2.5 b c$ & $95.5 \pm 32.1 c$ & $122.6 \pm 58.0 \mathrm{bc}$ & $370.8 \pm 125.1 \mathrm{a}$ & $59.2 \pm 4.0 \mathrm{c}$ & $201.0 \pm 63.3 b c$ & $284.6 \pm 120.8 \mathrm{ab}$ \\
\hline Total phenolics ${ }^{\S}$ & $2507 \pm 287 \mathrm{bcd}$ & $2221 \pm 256$ cde & $2579 \pm 150 \mathrm{bc}$ & $2647 \pm 287 b$ & $2135 \pm$ 100de & $4036 \pm 133 a$ & $2607 \pm 246 b c$ & $2003 \pm 257 e$ \\
\hline
\end{tabular}

Bold values refer to the sum of each colunm.

Means followed by the same letters in the same lines do not differ by Tukey test at $5 \%$ probability.

$\$$ Total monomeric anthocyanins quantified by the technic of difference of $\mathrm{pH}$ and expressed as equivalent to malvidin 3-glucoside.

$\S$ Total phenolics measured with Folin-Ciocalteu expressed as $\mathrm{mg} \mathrm{L}^{-1}$ equivalent to gallic acid.

consistent with the reported in the literature for commercial red wines of different world regions (range $282-3476 \mathrm{mg} \mathrm{L}^{-1}$ ) (Leeuw et al., 2014).

The values obtained for total monomeric anthocyanins by $\mathrm{pH}-$ differential method are also shown in Table 2. For the grape juice values ranged from 88.4 to $370.8 \mathrm{mg} \mathrm{L}^{-1}$. For red wines the anthocyanins monomeric values ranged from 59.2 to $284.6 \mathrm{mg} \mathrm{L}^{-1}$. The total monomeric anthocyanins concentrations obtained in juices are in accordance to the reported in the literature for commercial grape juice produced from Vitis labrusca L. cultivars in different regions of Brazil, whose values ranged from 74 to $424 \mathrm{mg} \mathrm{L}^{-1}$ (Margraf et al., 2016). For wines, the values are consistent with those reported by Lima et al. (2011) to Vitis labrusca L. cultivar Bordô originated from the South State of Paraná, South of Brazil. 


\subsubsection{Phenolic acids}

The results obtained for phenolic acids are shown in Table 2. The total amount of phenolic acids ranged from 247.1 to $410.1 \mathrm{mg} \mathrm{L}^{-1}$ for the grape juice, and 41.3 to $228.7 \mathrm{mg} \mathrm{L}^{-1}$ for wines. Regarding individual phenolic acids, caftaric acid was the major compound, with values ranging from 233.9 to $365.5 \mathrm{mg} \mathrm{L}^{-1}$ in samples of grape juice and 6.6 to $167.4 \mathrm{mg} \mathrm{L}^{-1}$ in wines.

Other studies that have characterized phenolic acids in grape juice and red wine Vitis labrusca L. cultivars also mentioned the caftaric acid as the main phenolic acid (Magro et al., 2016; Nixdorf \& Hermosín-Gutiérrez, 2010; Toaldo et al., 2015). According to Penna and Daudt (2001), caftaric acid is readily oxidisable during wine production steps, especially in fermentations, which could explain the lower values found in wine samples compared with grape juice.

The caftaric acid values obtained in the wine samples studied (6.6-167 $\mathrm{mg} \mathrm{L}^{-1}$ ) are in accordance with those mentioned by Nixdorf and Hermosín-Gutiérrez (2010) for wines of the variety Isabel (Vitis labrusca) produced in South of Brazil and with the range found in wine (Vitis vinifera L.) cultivars of several classical as Cabernet Sauvignon, Merlot, Malbec and Pinot Noir produced in several traditional countries in the production of wines like France, Argentina, Chile, Italy and United States, whose values ranged from 23.1 to $105.6 \mathrm{mg} \mathrm{L}^{-1}$ (Leeuw et al., 2014).

Samples of grape juice presented values of caftaric acid (233.9$365.5 \mathrm{mg} \mathrm{L}^{-1}$ ) greater than those reported in the literature for several samples of grape juice (L. Vitis labrusca and Vitis vinifera L.), conventional, organic and biodynamic, originated from South and Southeast of Brazil, Spain and other European countries, whose average values ranged from 6.0 to $222.9 \mathrm{mg} \mathrm{L}^{-1}$ (Granato et al., 2015; Moreno-Montoro, Olalla-Herrera, Gimenez-Martinez, Navarro-Alarcon, \& Rufián-Henares, 2015; Toaldo et al., 2015) suggesting that this compound may be an important chemical marker for grape juices of the new brazilian varieties produced in the São Francisco Valley (SFV), Northeast of Brazil. It is noteworthy that in studies that characterized phenolic compounds in grape juices produced in Brazil's Northeast was not evaluated the presence of caftaric acid (Lima et al., 2014, 2015; Natividade et al., 2013; Silva et al., 2015).

For hydroxybenzoic, gallic and syringic acids average values of the samples of juices range from 3.6 to 16.7 and 1.1 to $5.6 \mathrm{mg} \mathrm{L}^{-1}$, respectively. In wines values ranged from 1.1 to 16.9 and 2.1 to $26.4 \mathrm{mg} \mathrm{L}^{-1}$ for syringic and gallic acids, respectively. For hydroxycinnamic $\rho$-coumaric and caffeic acids, average values in grape juices ranged from 3.1 to 14.9 and 2.2 to $10 \mathrm{mg} \mathrm{L}^{-1}$, respectively. In wines average values for caffeic and $\rho$-coumaric acids ranged from 3.6 to 18.8 and 2.6 to $15.8 \mathrm{mg} \mathrm{L}^{-1}$, respectively.

The values obtained for the gallic, syringic, $\rho$-coumaric and caffeic acids in samples of grape juice and wine studied are in accordance with those mentioned in various characterizations of grape juices and wines produced with Vitis labrusca L. classical varieties like Isabel, Bordô and Concord (Lima et al., 2011; Magro et al., 2016; Margraf et al., 2016; Nixdorf \& Hermosín-Gutiérrez, 2010; Toaldo et al., 2015) and the above-mentioned amounts for juices new brazilian grape varieties cultivated in the Northeast of Brazil (Lima et al., 2014; Silva et al., 2015).

\subsubsection{Flavanols}

The total flavanols quantified ranged from 256.8 to $410.1 \mathrm{mg} \mathrm{L}^{-1}$ in grape juice and 187.9 to $309.1 \mathrm{mg} \mathrm{L}^{-1}$ in red wine (Table 2). Among the main individually quantified flavanol compound was found epigallocatechin whose concentration varied from 275.1 to $368.2 \mathrm{mg} \mathrm{L}^{-1}$ and 128.5 to $217.7 \mathrm{mg} \mathrm{L}^{-1}$ for samples in grape juice and red wine, respectively.

The epigallocatechin (PubChem CID: 72277) is a compound under study in grapes and derived products, which is usually fea- tured in green tea (Camellia sinensis L.) (El-Shahawi, Hamza, Bahaffi, Al-Sibaai, \& Abduljabbar, 2012). In derivatives of grape usually the epigallocatechin gallate, as mentioned by Mattivi, Vrhovsek, Masuero, and Trainotti (2009) is referred as a major monomeric flavanols present in Vitis vinifera grape skin extracts as Cabernet Sauvignon, Merlot, Syrah, Pinot Noir, Teroldego and Marzemino.

The epigallocatechin values obtained in the samples of wine and commercial grape juices of SFV were considered high because represented between 5.37 and $14.27 \%$ of the total phenolics content, respectively, indicating that this compound can deal with a major chemical marker which characterizes the products of this region.

The procyanidin B2 values in grape juices ranged from 5.8 to $17.0 \mathrm{mg} \mathrm{L}^{-1}$ and from 23.6 to $29.3 \mathrm{mg} \mathrm{L}^{-1}$ in wines. For procyanidin $\mathrm{B} 1$ values in the grape juice samples $\left(5.8-17 \mathrm{mg} \mathrm{L}^{-1}\right)$ were lower than in wine (23.6-29.3 $\left.\mathrm{mg} \mathrm{L}^{-1}\right)$. For catechin values obtained ranged from 7.4 to $15 \mathrm{mg} \mathrm{L}^{-1}$ and 9.8 to $24.5 \mathrm{mg} \mathrm{L}^{-1}$ in samples of grape juice and wine, respectively. Regarding epicatechin gallate values ranged from not detected to $3.3 \mathrm{mg} \mathrm{L}^{-1}$ in all samples.

The values found in this study to procyanidin B1 and B2, catechin and epicatechin gallate are in accordance with the range of values mentioned in several works that characterized grape juices and red wines from classic Vitis labrusca cultivars as Isabel, Bordô and Concord in the South and Southeast of Brazil (Granato et al., 2015; Lima et al., 2011; Toaldo et al., 2015); also being according to the values mentioned above for grape juices of new varieties of brazilian grapes planted in the Northeast of Brazil (Lima et al., 2014; Silva et al., 2015).

\subsubsection{Individual anthocyanins}

The total number of individual anthocyanins quantified by HPLC ranged from 8.9 to $203.5 \mathrm{mg} \mathrm{L}^{-1}$ in analyzed samples of wine and grape juice (Table 2). Among the main anthocyanins found in samples, in decreasing order, were malvidin 3.5-diglucoside, malvidin-3-0-glucoside and cyanidin 3,5-diglucoside, which showed heterogeneous profile in the studied commercial products, as previously noted by Lima et al. (2014) to the new brazilian juice grape varieties.

For malvidin 3,5-diglucoside values ranged from 8.9 to $136.5 \mathrm{mg} \mathrm{L}^{-1}$ and $<\mathrm{LD}$ to $53.7 \mathrm{mg} \mathrm{L}^{-1}$ in samples of juices and wines, respectively. The malvidin-3-0-glucoside showed values ranging from 3.3 to 36.8 and 2.4 to $7.7 \mathrm{mg} \mathrm{L}^{-1}$ in grape juice and wine samples, respectively. For cyanidin 3,5-diglucoside in grape juice and wine the range of values found varied from $<$ LD to 13.2 and 25.1 to $0.8 \mathrm{mg} \mathrm{L}^{-1}$, respectively.

The values obtained for anthocyanins in grape juice and wine studied here are in agreement with the values found for a range of commercial juices and wines produced with from $V$. labrusca cultivars and hybrids derived from Brazil (Granato et al., 2015; Lago-Vanzela et al., 2013; Lima et al., 2015; Nixdorf \& HermosínGutiérrez, 2010).

\subsubsection{Antioxidant activity}

The in vitro antioxidant activity of grape juice and wine was measured by sequestering methods of free radicals (DPPH and ABTS) and reactive oxygen species $\left(\mathrm{H}_{2} \mathrm{O}_{2}\right)$, both expressed as equivalent to Trolox in millimoles per liter of sample $\left(\mathrm{mM} \mathrm{TEAC}^{-1}\right)$ (Fig. 4).

In grape juice samples, antioxidant activity (AOX) measured by DPPH and ABTS ranged from 10.03 to 14.38 and 12.47 to 18.13 TEAC $\mathrm{mM} \mathrm{L}^{-1}$, respectively. In red wines the values ranged from 10.89 to 18.28 and 17.65 to $29.21 \mathrm{mM} \mathrm{TEAC}^{-1}$ to DPPH and ABTS, respectively.

The AOX-values obtained by DPPH and ABTS in the grape juice samples studied are accordance on various papers that character- 


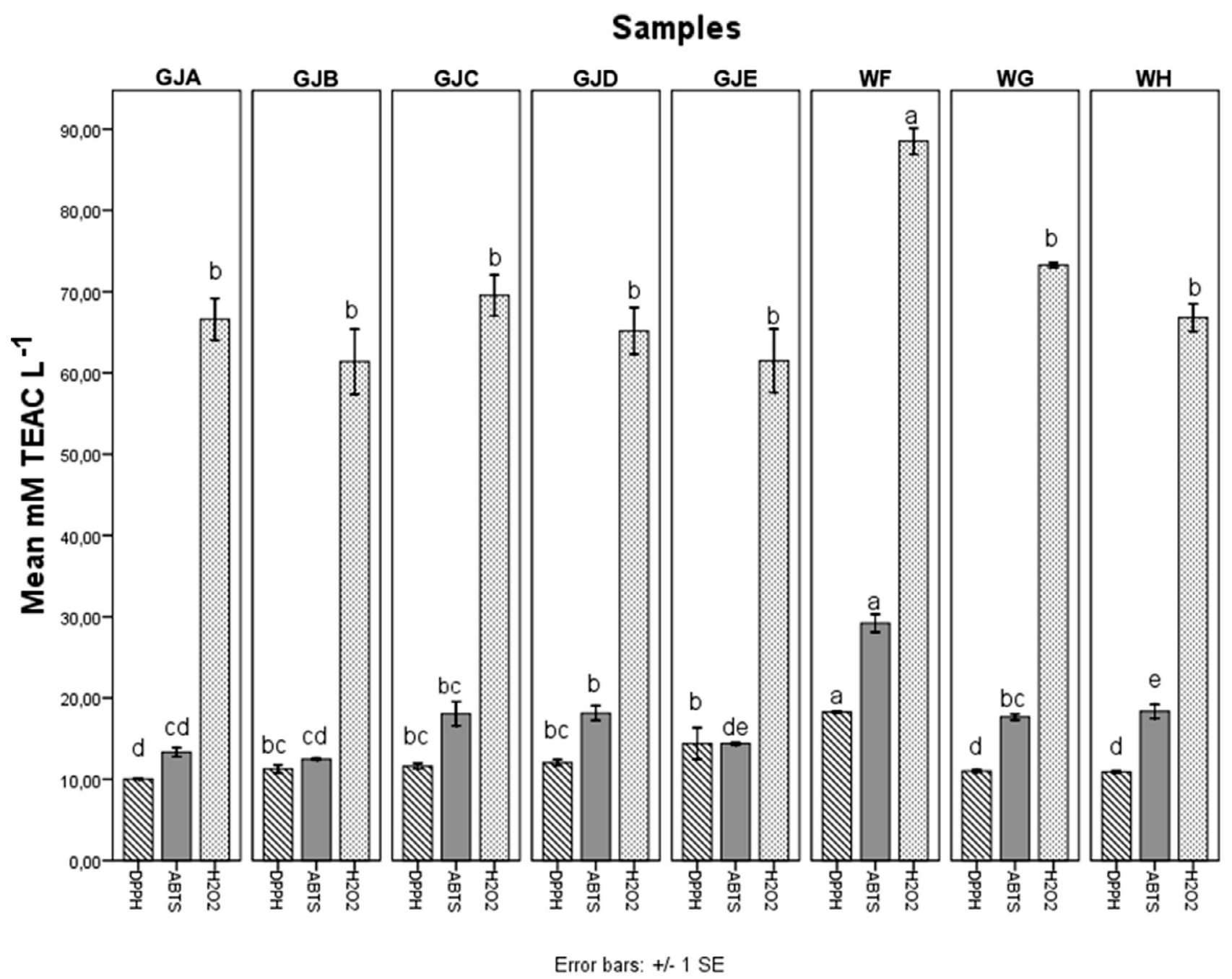

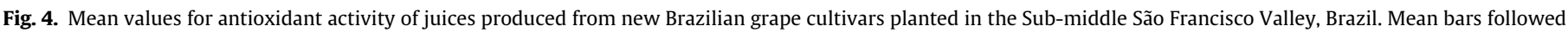
by the same letters between juices do not differ according to the Tukey test at 5\% probability.

ized grape juices from different regions of origin, species, cultivars, cultivation systems and process conditions where the values AOX normally reach up to 27 mM TEAC L ${ }^{-1}$ (Granato et al., 2016). With exceptions for juices of the new brazilian grape varieties planted in the Northeast of Brazil and juices (Vitis labrusca L.) originated from Santa Catarina - Brazil where are mentioned values of up to 54.19 $\mathrm{mM} \mathrm{TEAC} \mathrm{L}^{-1}$ to DPPH and ABTS (Lima et al., 2014; Toaldo et al., 2015).

Regarding the wine samples studied the AOX values were high because the highest value of AOX (DPPH and ABTS) found in the literature was $23.17 \mathrm{mM} \mathrm{TEAC}^{-1}$ in wine Vitis vinifera $\mathrm{L}$. of Santa Catarina, South Brazil by the method with ABTS (Gris et al., 2011). In a study conducted by Leeuw et al. (2014) were evaluated 38 classic varieties of wine samples as Cabernet Sauvignon, Merlot, Syrah, Pinot Noir and Malbec from countries like France, Italy, United States, Chile, Australia and Argentina, where the AOX values ranged from 3.71 to 7.67 TEAC $\mathrm{mM} \mathrm{L}^{-1}$ by the method with DPPH. In wine cultivar Isabel (Vitis labrusca L.) produced in the states of Paraná and Rio Grande do Sul, South Brazil, the AOX values ranged 2.6-6.3 mM TEAC $\mathrm{L}^{-1}$ measured with DPPH (Nixdorf \& HermosínGutiérrez, 2010), highlighting the high antioxidant activity obtained in commercial wines analyzed in this study.

A wide variety of in vitro antioxidant activity measurement methods have been used for characterization of grape juice and wine. In addition to the DPPH and ABTS, methods such as Oxygen Radical Absorbance Capacity (ORAC), ThioBarbituric Acid Reactive Substances (TBARS) and Ferric Reducing Antioxidant Power (FRAP) has been widely used (Granato, Katayama, \& Castro, 2011; Granato et al., 2016; Gris et al., 2011; Lima et al., 2014). Few studies in the literature have measured the antioxidant activity of products derived from the grape by the sequestering method of hydrogen peroxide.

The ability of the samples analyzed in this study to eliminate hydrogen peroxide $\left(\mathrm{H}_{2} \mathrm{O}_{2}\right)$ is shown in Fig. 4. The scavenging activity of hydrogen peroxide ranged from 66.81 to 88.52 and 61.39 to $69.54 \mathrm{mM} \mathrm{TEAC} \mathrm{L}^{-1}$ in samples of wine and grape juices, respectively.

Camargo et al. (2014) evaluated the antioxidant activity of waste processing of grape juices (BRS Cora and Isabel Precoce) and wines (Syrah and Tempranillo) originated from the Submiddle São Francisco Valley (SFV), Northeast Brazil, using $\mathrm{H}_{2} \mathrm{O}_{2}$ sequestering method and found values ranging from 143 to 167

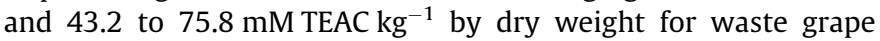
juices and wines, respectively.

Reactive oxygen species (ROS) include radicals such as superoxide anion $\left(\mathrm{O}_{2}^{-}\right)$, hydroxyl radical ( $\left.\mathrm{HO} \cdot\right)$, perhydroxyl radical (HOO*) and non-radical hydrogen peroxide $\left(\mathrm{H}_{2} \mathrm{O}_{2}\right)$ are associated with various pathological mechanisms that contribute with diseases such 
as diabetes, cancer, cardiovascular and neurodegenerative diseases (Roleira et al., 2015). It is widely known that foods rich in phenolic compounds, such as grape juice and wine, are usually associated with prevention of various diseases in humans where antioxidant activity is related to protection mechanisms, including serving on the inhibition of ROS (Oroian \& Escriche, 2015; Roleira et al., 2015). Based on the above, there is a need to conduct larger studies correlating in vitro antioxidant activity for the sequestering method of $\mathrm{H}_{2} \mathrm{O}_{2}$ radical in grape juice and wine with any protection mechanisms to the health of consumers.

The $\mathrm{H}_{2} \mathrm{O}_{2}$ antioxidant activity of juices and wines studied here can be considered high, suggesting that products made with new grape varieties from Northeastern Brazil may have a great ability in inhibiting ROS.

\section{Conclusions}

Based on the results obtained for the validation parameters, the method for rapid determination of 15 phenolic compounds in wine and juices by RP-HPLC-DAD using a new rapid resolution column of the type RP-C18 $(100 \times 4.6 \mathrm{~mm}, 3.5 \mu \mathrm{m})$ proved to be suitable for use in research on these subjects. The method showed linearity, precision, accuracy, recovery and limits of detection and quantification according to other methods previously published for the determination of phenolic compounds by RP-HPLC, with the difference of having a runtime of only $25 \mathrm{~min}$. The applicability of the validated method was verified by characterization of phenolic compounds in grape juices and commercial wines from new brazilian grape varieties, where the results differed from the products studied juices and wines from other world regions, mainly because of the high values of (-)-epigallocatechin and trans-caftaric acid. Regarding the bioactive potential, the samples showed high antioxidant activity, especially the red wine samples with the values higher than of wines from different world regions. The $\mathrm{H}_{2} \mathrm{O}_{2}$ antioxidant activity of studied juices and wines was considered high, suggesting that products made with new grape varieties of Brazilian Northeast of Brazil may have a great ability in inhibiting ROS.

\section{Acknowledgments}

The authors would like to acknowledge the Conselho Nacional de Desenvolvimento Científico e Tecnológico (CNPq) for granting a scholarship and the Instituto Federal do Sertão Pernambucano for the financial support.

\section{References}

Agilent (2008). Agilent ChemStation for LC 3D Systems: Understanding Your Spectra Module. Agilent Technologies, Inc., Ed. 06/08 Waldbronn, Germany, 46p. Accessible in: https://www.agilent.com/cs/library/usermanuals/Public/ G2180-90024_spectra_ebook.pdf.

BRASIL (2011). Ministério da Agricultura, Pecuária e Abastecimento. Guia de Validação e Controle de Qualidade Analítica: Fármacos em Produtos para Alimentação Animal e Medicamentos Veterinários. Secretaria de Defesa Agropecuária, Brasília, 2011. Available in: http://www.agricultura.gov.br/arq editor/file/Laboratorio/Guia-de-validacao-controle-de-qualidade-analitica.pdf.

Camargo, A. C., Regitano d'Arce, M. A. B., Biasoto, A. C. T., \& Shahidi, F. (2014). Low molecular weight phenolics of grape juice and wine-making by-products: Antioxidant activities and inhibition of oxidation of human LDL-cholesterol and DNA strand breakage. Journal of Agricultural and Food Chemistry, 62(50), 12159-12171.

Dias, F. de. S., David, J. M., \& David, J. P. (2016). Determination of phenolic acids and quercetin in Brazilian red wines from Vale do São Francisco region using liquidliquid ultrasound-assisted extraction and HPLC-DAD-MS. Journal of the Brazilian Chemical Society, 26(7), 1055-1059.

El-Shahawi, M. S., Hamza, A., Bahaffi, S. O., Al-Sibaai, A. A., \& Abduljabbar, T. N. (2012). Analysis of some selected catechins and caffeine in green tea by high performance liquid chromatography. Food Chemistry, 134, 2268-2275.
Eurachem Guide: The Fitness for Purpose of Analytical Methods - A Laboratory Guide to Method Validation and Related Topics, (2nd ed. 2014). ISBN 978-9187461-59-0. Available from http://www.eurachem.org.

Fontana, A. R., Antoniolli, A., \& Bottini, R. (2016). Development of a high performance liquid chromatography method based on a core-shell column approach for the rapid determination of multiclass polyphenols in grape pomaces. Food Chemistry, 192, 1-8.

Garrido, J., \& Borges, F. (2013). Wine and grape polyphenols - A chemical perspective. Food Research International, 54(2), 1844-1858.

Giusti, M. M., \& Wrolstad, R. E. (2001). Characterization and measurement of anthocyanins by UV-Visible spectroscopy. In Current protocols in food analytical chemistry. New York, USA: John Wiley and Sons Inc.

Granato, D., Calado, V. M. A., \& Jarvis, B. (2014). Observations on the use of statistical methods in Food Science and Technology. Food Research International, 55, 137-149.

Granato, D., Carrapeiro, M. M., Fogliano, V., \& van Ruth, S. M. (2016). Effects of geographical origin, varietal and farming system on the chemical composition and functional properties of purple grape juices: A review. Trends in Food Science and Technology, 52, 31-48.

Granato, D., Katayama, F. C. U., \& Castro, I. A. (2011). Phenolic composition of South American red wines classified according to their antioxidant activity, retail price and sensory quality. Food Chemistry, 129(2), 366-373.

Granato, D., Koot, A., Schnitzler, E., \& van Ruth, S. M. (2015). Authentication of geographical origin and crop system of grape juices by phenolic compounds and antioxidant activity using chemometrics. Journal of Food Science, 80(3), C584-C593.

Gris, E. F., Mattivi, F., Ferreira, E. A., Vrhovsek, U., Pedrosa, R. C., \& Bordignon-Luiz, M. T. (2011). Proanthocyanidin profile and antioxidant capacity of Brazilian Vitis vinifera red wines. Food Chemistry, 126(1), 213-220.

Hubaux, A., \& Vos, G. (1970). Decision and detection limits for linear calibration curves. Analytical Chemistry, 42, 849-855.

Kim, Y. K., Guo, Q., \& Packer, L. (2002). Free radical scavenging activity of red ginseng aqueous extracts. Toxicology, 172(2), 149-156.

Lago-Vanzela, E. S., Rebello, L. P. G., Ramos, A. M., Stringheta, P. C., Da-Silva, R., García-Romero, E., ... Hermosín-Gutiérrez, I. (2013). Chromatic characteristics and color-related phenolic composition of Brazilian young red wines made from the hybrid grape cultivar BRS Violeta ("BRS Rúbea"× "IAC 1398-21"). Food Research International, 54(1), 33-43.

Lambri, M., Torchio, F., Colangelo, D., Río Segade, S., Giacosa, S., De Faveri, D. M., \& Rolle, L. (2015). Influence of different berry thermal treatment conditions, grape anthocyanin profile, and skin hardness on the extraction of anthocyanin compounds in the colored grape juice production. Food Research International, 77, 584-590.

Leeuw, R., Kevers, C., Pincemail, J., Defraigne, J. O., \& Dommes, J. (2014). Antioxidant capacity and phenolic composition of red wines from various grape varieties: Specificity of Pinot Noir. Journal of Food Composition and Analysis, 36(1-2) 40-50.

Lima, D. B., Agustini, B. C., Silva, E. G., Gaensly, F., Cordeiro, R. B., Fávero, M. L. D., Bonfim, T. M. B. (2011). Evaluation of phenolic compounds content and in vitro antioxidant activity of red wines produced from Vitis labrusca grapes. Food Science and Technology, 31(3), 793-800.

Lima, M. D. S., Silani, I. D. S. V., Toaldo, I. M., Corrêa, L. C., Biasoto, A. C. T., Pereira, G. E., ... Ninow, J. L. (2014). Phenolic compounds, organic acids and antioxidant activity of grape juices produced from new Brazilian varieties planted in the Northeast Region of Brazil. Food Chemistry, 161, 94-103.

Lima, M. S., da Conceição Prudêncio Dutra, M., Toaldo, I. M., Corrêa, L. C., Pereira, G. E., de Oliveira ... Ninow, J. L. (2015). Phenolic compounds, organic acids and antioxidant activity of grape juices produced in industrial scale by different processes of maceration. Food Chemistry, 188, 384-392.

Magro, L., Goetze, D., Ribeiro, C. T., Paludo, N., Rodrigues, E., Hertz, P. F., ... Rodrigues R. C. (2016). Identification of bioactive compounds from Vitis labrusca L. variety concord grape juice treated with commercial enzymes: improved yield and quality parameters. Food and Bioprocess Technology, 9(2), 365-377.

Manns, D. C., \& Mansfield, A. K. (2012). A core-shell column approach to a comprehensive high-performance liquid chromatography phenolic analysis of Vitis vinifera L. and interspecific hybrid grape juices, wines, and other matrices following either solid phase extraction or direct injection. Journal of Chromatography A, 1251, 111-121.

Margraf, T., Santos, É. N. T., Andrade, E. F., van Ruth, S. M., \& Granato, D. (2016) Effects of geographical origin, variety and farming system on the chemical markers and in vitro antioxidant capacity of Brazilian purple grape juices. Food Research International, 82, 145-155.

Mattivi, F., Vrhovsek, U., Masuero, D., \& Trainotti, D. (2009). Differences in the amount and structure of extractable skin and seed tannins amongst red grape varieties. Australian Journal of Grape and Wine Research, 15(1), 27-35.

Moreno-Montoro, M., Olalla-Herrera, M., Gimenez-Martinez, R., Navarro-Alarcon, M., \& Rufián-Henares, J. A. (2015). Phenolic compounds and antioxidant activity of Spanish commercial grape juices. Journal of Food Composition and Analysis, 38 , 19-26.

Natividade, M. M. P., Corrêa, L. C., Souza, S. V. C., Pereira, G. E., \& Lima, L. C. D. O (2013). Simultaneous analysis of 25 phenolic compounds in grape juice for HPLC: Method validation and characterization of São Francisco Valley samples. Microchemical Journal, 110, 665-674.

Nixdorf, S. L., \& Hermosín-Gutiérrez, I. (2010). Brazilian red wines made from the hybrid grape cultivar Isabel: Phenolic composition and antioxidant capacity. Analytica Chimica Acta, 659(1-2), 208-215. 
Òbon, J. M., Díaz-Garcia, M. C., \& Castelllar, M. R. (2011). Red fruit juice quality and authenticity control by HPLC. Journal of Food Composition and Analysis, 24(6), $760-771$.

Oroian, M., \& Escriche, I. (2015). Antioxidants: Characterization, natural sources extraction and analysis. Food Research International, 74, 10-36.

Penna, N. G., \& Daudt, C. E. (2001). Comportamento de ésteres hidroxicinâmicos Material e Métodos. Pesquisa Agropecuária Brasileira, 1, 983-989.

Re, R., Pellegrini, N., Proteggente, A., Pannala, A., Yang, M., \& Rice-Evans, C. (1999). Antioxidant activity applying an improved ABTS radical cation decolorization assay. Free Radical Biology and Medicine, 26(9-10), 1231-1237.

Roleira, F. M. F., Tavares-Da-Silva, E. J., Varela, C. L., Costa, S. C., Silva, T., Garrido, J., \& Borges, F. (2015). Plant derived and dietary phenolic antioxidants: Anticancer properties. Food Chemistry, 183, 235-258.

Ruch, R. J., Cheng, S. J., \& Klaunig, J. E. (1989). Prevention of cytotoxicity and inhibition of intercellular communication by antioxidant catechins isolated from Chinese green tea. Carcinogen, 10, 1003-1008.

Silva, J. K., Cazarin, C. B. B., Correa, L. C., Batista, Â. G., Furlan, C. P. B., Biasoto, A. C. T. ... Maróstica Junior, M. R. (2015). Bioactive compounds of juices from two
Brazilian grape cultivars. Journal of the Science of Food and Agriculture, 96, 1990-1996.

Scola, G., Conte, D., Spada, P. W. D. S., Dani, C., Vanderlinde, R., Funchal, C., \& Salvador, M. (2010). Flavan-3-ol compounds from wine wastes with in vitro and in vivo antioxidant activity. Nutrients, 2(10), 1048-1059.

Singleton, V. L., \& Rossi, J. A. (1965). Colorimetry of total phenolics with phosphomolybdic phosphotungstic acid reagents. American Journal of Enology and Viticulture, 16, 144-158.

Tarola, A. M., Milano, F., \& Giannetti, V. (2007). Simultaneous determination of phenolic compounds in red wines by HPLC-UV. Analytical Letters, 40(12), 2433-2445.

Toaldo, I. M., Cruz, F. A., Alves, T., de, L., Gois, J. S., Borges, D. L. G., ... Bordignon-Luiz, M. T. (2015). Bioactive potential of Vitis labrusca L. grape juices from the Southern Region of Brazil: Phenolic and elemental composition and effect on lipid peroxidation in healthy subjects. Food Chemistry, 173, 527-535.

Toscano, L. T., Tavares, R. L., Toscano, L. T., da Silva, C. S. O., de Almeida, A. E. M., Biasoto, A. C. T., ... Silva, A. S. (2015). Potential ergogenic activity of grape juice in runners. Applied Physiology, Nutrition E' Metabolism, 40(9), 899-906. 